\title{
Thermal Bridge Impact on the Heating Demand in a Low-Energy House
}

\author{
Martins Pelss, Institute of Energy Systems and Environment, Riga Technical University, Andra Blumberga, Institute \\ of Energy Systems and Environment, Riga Technical University, Agris Kamenders, Institute of Energy Systems and \\ Environment, Riga Technical University
}

\begin{abstract}
Thermal bridges typically occur at the junction of different building components where it is difficult to achieve continuity in the thermal insulation layer. In this paper thermal bridges are investigated in the first one-family low-energy house in Latvia. The proportion of the overall heat loss due to thermal bridging is determined based on the results from a numerical calculation method described in the standard LVS EN ISO 10211 and from the simplified calculation method given in the standard LVS EN ISO 14683. In this paper the software tool THERM is used for two-dimensional thermal bridge model simulations. The results suggest that $7.7 \%$ of the total heat transmission losses occur due to thermal bridges.
\end{abstract}

Keywords -detailed thermal bridge calculation method, linear thermal transmittance, low-energy house.

\section{INTRODUCTION}

Climate change is one of the most critical challenges facing humanity today. The process of climate change unleashed by the rapid rise of atmospheric greenhouse gas emissions, historically and today, has the capacity to completely change our every day life.

To minimize the adverse impacts of climate change we can start with our homes by building them so well, that they consume no or just a little energy like it is in low-energy houses. Energy production is a mayor cause of atmospheric greenhouse gas emissions, however energy is simply lost through the building envelope as heat. Insulating walls represents one of the simplest solutions for decreasing the building's heat losses. Low-energy houses use thick insulation layers, but it this not necessarily a sufficient solution to reduce heat losses, since at some junctions it is difficult to achieve continuity in the thermal insulation layer. At these junctions thermal bridges typically occur, therefore they have to be addressed specifically or otherwise the increase in the amount of insulation of the building will just heighten the weight of thermal bridges in the overall heat-energy consumption [1].

Generally the term low-energy houses refers to buildings that consume $20-30 \mathrm{kWh} / \mathrm{m}^{2}$ thermal energy for space heating per year and they are expected to become the dominant type of one-family house in the near future, therefore by learning the lessons of the past it is possible to build buildings with predictable energy consumption. This means that thermal bridges have to be included in calculations already at the design stage. This was not common in previous practice and there is still a gap of knowledge about transmission heat losses through thermal bridges in different kinds of construction solutions.

The aim of this paper is to investigate thermal bridges in the first one-family low-energy building in Latvia in order to determine the proportion of the transmission heat losses due to thermal bridging in low-energy buildings in general. This is done using results from the numerical calculation method. The numerical calculation method is described in the standard LVS EN ISO 10211 [2] and it is used in determining the thermal performance of building details in a precise way. This method requires a software tool for two-dimensional thermal bridge model simulations. Since there is an established practice to create thermal bridge atlases [3, 4] using the software tool THERM [5] and it is valid to use THERM according to the LVS EN ISO 10211 standard, this software was chosen.

On the contrary, the simplified calculation method given in standard LVS EN ISO 14683 [6] was used for calculating transmission losses due to thermal bridges in the same low-energy building.

\section{Methodology}

According to the Latvian Building Code LBN 002-01 [7], the linear thermal bridge heat transfer value should be calculated using the methods described in standard LVS EN ISO 10211 [2]. This method is known as the detailed calculation method, since it uses computer software and requires specific knowledge. The Building Code also permits the use of the calculation method described in standard LVS EN ISO 14683 [6] which is known as the simplified method. This method utilizes thermal bridge catalogues. The catalogue is not specifically adjusted for the typical construction solutions used in Latvia. Both calculation methods were used to estimate thermal bridge impact on heat loss through the envelope of the first lowenergy one-family house in Latvia.

The low-energy house "Lielkalni" is situated in the village Gipka which is within the Rojas municipality. It is a two-storey house with a living space of $190 \mathrm{~m}^{2}$. The house was built in 2009, but it is inhabited since March 2010. First estimates suggest, that this house will require 22-27 $\mathrm{kWh} / \mathrm{m}^{2}$ thermal energy/annum. The low-energy house is illustrated in Figure 1. 


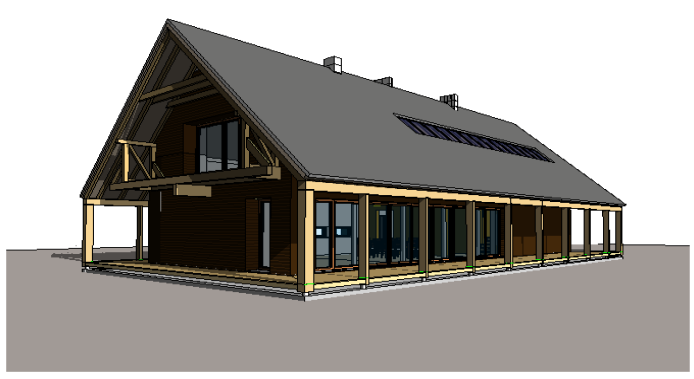

Fig. 1. The first low-energy house in Latvia - "Lielkalni".

It is important to stress the properties of materials that the building's envelope consists of, since they have great impact on the thermal transmittance of building elements and therefore on the linear thermal transmittance obtained according to $(1)[8,1]$.

$$
\psi=L^{2 D}-\sum_{i=1}^{I} U_{i} l_{i}
$$

where:

$\psi$ - linear thermal transmittance $(\mathrm{W} / \mathrm{m} \cdot \mathrm{K})$;

L2D - thermal coupling coefficient from two-dimensional (2D) calculation $(\mathrm{W} / \mathrm{m} \cdot \mathrm{K})$;

$\mathrm{U}_{\mathrm{j}}$ - thermal transmittance of the one-dimensional (1-D) component $j$ separating two environments $\left(\mathrm{W} / \mathrm{m}^{2} \cdot \mathrm{K}\right)$;

$\mathrm{l}_{\mathrm{j}}$ - length within the two-dimensional geometrical model over which the $\mathrm{U}_{\mathrm{j}}$ applies (m).
The thermal coupling coefficient was calculated using the software THERM, according to the criteria specified by LVS EN ISO 10211. The heat loss from each of the 1-D was then subtracted from the heat loss as calculated by the 2-D model. This provides the linear thermal transmittance of the thermal bridge.

THERM is a software program that utilises the finite-element method to model steady-state, two-dimensional heat-transfer problems. The program is developed at the Lawrence Berkeley National Laboratory and is free of charge [9]. THERM allows one to model two-dimensional heat-transfer effects in building components where thermal bridges are an issue. Its heat-transfer analysis allows one to evaluate a building element's energy efficiency and local temperature patterns, which may relate directly to issues of condensation, moisture damage and structural integrity [5]. This software has been widely used in many applications, for instance to create thermal bridge catalogues $[4,3]$. In order to classify this calculation method as a high precision method (accuracy $\pm 5 \%$ ), a software validation test according to standard LVS EN ISO 10211 was conducted [2]. The results from the test reference cases proved that THERM is appropriate for the detailed calculation method.

The thermal transmittances of building elements and corresponding materials are given in Table I. Thermal transmittances are calculated according to the standard LVS EN ISO 6946 [10]. The thermal conductivities of materials are already given with correction coefficients taken from the Latvian Building Code LBN 002-01 [7]. Window frame thermal transmittances were also obtained by constructing a window frame model in THERM according to drawings provided by the window manufacturers.

TABLE I

A LIST OF BUILDING ELEMENTS AND MATERIALS USED IN LOW-ENERGY BUILDING EVELOPE

\begin{tabular}{|l|l|l|l|}
\hline Building element & Thickness, $\mathbf{~ m m}$ & Thermal conductivity, W/(m·K) & Thermal transmittance, $\mathbf{W} /\left(\mathbf{m}^{2} \cdot \mathbf{K}\right)$ \\
\hline \hline Outer wall & & & $\mathbf{0 . 0 8 0}$ \\
\hline expanded clay blocks & 250 & 0.220 & \\
\hline mineral wool & 500 & 0.040 & \\
\hline wind barrier & 25 & 0.065 & $\mathbf{0 . 0 6 7}$ \\
\hline \hline Roof on slopes & & & \\
\hline wood wool cement board & 75 & 0.071 & \\
\hline OSB sheathing board & 22 & 0.180 & \\
\hline mineral wool & 600 & 0.040 & \\
\hline wind barrier & 25 & 0.065 & $\mathbf{0 . 0 5 1}$ \\
\hline \hline Roof on top & & & \\
\hline wood wool cement board & 100 & 0.071 & \\
\hline OSB sheathing board & 22 & 0.180 & \\
\hline mineral wool & 836 & 0.040 & $\mathbf{0 . 1 0 0}$ \\
\hline wind barrier & 25 & 0.065 & \\
\hline \hline Slab & & & \\
\hline wooden floor & 30 & 0.130 & \\
\hline plasterboard & 25 & 0.250 & $\mathbf{1 . 1 5 0}$ \\
\hline expanded clay & 150 & 0.210 & \\
\hline reinforced concrete & 260 & 2.500 & \\
\hline foam glass & 700 & 0.080 & \\
\hline \hline Frame of windows and doors, the first floor façade & 145 & & \\
\hline \hline Roof windows & 135 & & \\
\hline
\end{tabular}


In Table I material layers are arranged starting with the ones closest to the cold surface of the building elements. Boundary conditions used in thermal bridge models were chosen from the standard LVS EN ISO 6946. This means that the outdoor air temperature is $0^{\circ} \mathrm{C}$, while the indoor air temperature is set to $+20^{\circ} \mathrm{C}$.

For all parts of the building construction external dimensions were used. THERM allows controlling parameters of mesh. For all calculations Quad Tree mesh parameter was set as 6, but Error Estimator was allowed to make maximum of 25 iterations.

The detailed calculation method is precise but time consuming, since each type of thermal bridge requires a separate 2-D model and the linear thermal transmittance coefficient has to be calculated manually when using software like THERM. Thus it is tempting to use thermal bridges atlases. However, the main problem with these atlases is that in many countries they have not been created based on the typical constructions used in those countries. Since there is no thermal bridge atlas in Latvia, according to the Latvian Building Code one should use the atlas that is given in the standard LVS EN ISO 14683 and expect a linear thermal transmittance calculation accuracy of $\pm 50 \%$ [6]. In order to see how misleading results can get when an inappropriate atlas is chosen, the simplified thermal bridge calculation method was used for the same low-energy building.

The location of the insulation layer was the most important criteria when selecting default values from the atlas. The thermal bridge atlas does not present any example with a roof on slopes, so the default value of a flat roof with continuous outer insulation was chosen. None of the thermal bridge examples represent construction where the outer wall insulation is connected with the insulation beneath the slab, which is typical of low-energy and passive houses [4, 11]. More default values should be added to the atlas, since some thermal bridges cannot be assessed, for instance, at points where ventilation ducts or crossbeams cross the building envelope. The default values chosen and their impact on the overall transmission heat transfer coefficient of the building envelope $\left(\mathrm{H}_{\mathrm{T}}\right)$ are presented in Table II along with the results from the detailed calculation method.

Thermal bridge impact on heat loss of building and therefore heat energy requirement is defined as the proportion of heat loss through the linear thermal bridges against the total transmission heat losses through the building envelope [12]. The overall transmission heat transfer coefficient of the building envelope consists of two components. One component is the transmission heat losses through the building elements (1-D heat flow), but the second component is the transmission heat losses through the thermal bridges (2-D heat flow). All linear thermal transmittances (even negative ones) were taken into account when calculating $\mathrm{H}_{\mathrm{T}}$ according to (2).

$$
H_{T}=\sum_{i=1}^{I} U_{i} \cdot A_{i}+\sum_{k=1}^{K} \psi_{k} \cdot l_{k}
$$

where:
$\mathrm{A}_{\mathrm{i}}$ - area over which Ui applies $\left(\mathrm{m}^{2}\right)$;

$\psi_{\mathrm{k}}$ - linear thermal transmittance of building junction $\mathrm{k}$

$(\mathrm{W} / \mathrm{m} \cdot \mathrm{K})$;

$\mathrm{l}_{\mathrm{k}}$ - length over which $\psi_{\mathrm{k}}$ applies $(\mathrm{m})$.

When calculating the proportion of heat loss through thermal bridges in total transmission heat losses through the building envelope (\%), only the heat losses through thermal bridges that cause extra heat loss through the building envelope were considered. According to the standard, only the thermal bridges with a linear heat transfer coefficient $\psi \geq 0,01$ $\mathrm{W} /(\mathrm{m} \cdot \mathrm{K})$ should be used when calculating $\mathrm{H}_{\mathrm{T}, \psi \geq 0,01}$ that is used in (3) [2].

$$
\frac{H_{T, \psi \geq 0,01}}{H_{T}} \cdot 100
$$

where:

HT, $\psi \geq 0,01$ - transmission heat transfer coefficient's thermal bridges component;

HT - overall transmission heat transfer coefficient of the building envelope calculated according to (2).

\section{RESULTS}

In this study thermal bridges were found at 12 different junctions of building elements in the low-energy building. Each of thermal bridge is characterized by linear thermal transmittance $\left(\psi_{\mathrm{k}}\right)$ and length $\left(l_{\mathrm{k}}\right)$. By multiplying these two properties, we determined what this thermal bridge adds to the overall transmission heat transfer coefficient of the low-energy building $\left(\mathrm{H}_{\mathrm{T}}\right)$. The main results of this survey are given in Table II. Results from the simplified calculation method are given in comparison with the results obtained using the more accurate detailed calculation method. The results demonstrate the necessity of applying the detailed thermal bridge calculation for low-energy buildings in general. These buildings all have building envelopes with a thick insulation layer leading to much lower thermal transmittance of building elements than those used to create the thermal bridge atlas presented in the standard LVS EN ISO 14683 [6].

The results suggest that the simplified calculation method can lead to an error well over $50 \%$ if applied to well-insulated buildings, such as low-energy buildings. The greatest differences were found with regard to the thermal bridges that did not have an appropriate thermal bridge example in the atlas. If the insulation layer position in the thermal bridge atlas was essentially different from its position in the building's envelope, the mistake was well over the limits of accuracy given in the standard LVS EN ISO 14683 [6]. As said before, this problem was found with thermal bridge at the junction of wall and slab on ground. The linear thermal bridge thermal transmittance was much lower at the junctions of the wall and window frame. As this type of thermal bridge is typically one of the longest in the building, the atlas should be updated with examples where jambs are inclined. The simplified method also fails to describe thermal bridges that are caused by penetrations of various services such as ventilation ducts and 
chimneys. These type of thermal bridges are marked with "-" symbol in Table II. Results show that in conditions of no alternative calculation methods, it would be more appropriate to simply ignore thermal bridges than to try to estimate them using the simplified calculation method given in the standard
LVS EN ISO 14683. Data in Table II is arranged starting with thermal bridges that have the greatest impact on extra heat loss through the building envelope.

TABLE II

THERMAL BRIDGES IN LOW-ENERGY BUILDING - RESULTS FROM BOTH SIMPLIFIED AND DETAILDED CALCULATION METHODS

\begin{tabular}{|c|c|c|c|c|c|c|}
\hline \multirow{2}{*}{ Thermal bridge } & \multirow{2}{*}{$\begin{array}{l}\text { Thermal } \\
\text { bridge } \\
\text { denotation } \\
\text { according to } \\
\text { ISO } 14683\end{array}$} & \multirow{2}{*}{$\begin{array}{l}\text { Length of linear } \\
\text { thermal bridge, } \\
\mathrm{l}_{\mathrm{k}}, \mathrm{m}\end{array}$} & \multicolumn{2}{|c|}{$\begin{array}{l}\text { Linear thermal transmittance } \\
\psi_{\mathrm{k}}, \mathrm{W} /(\mathbf{m} \cdot \mathbf{K})\end{array}$} & \multicolumn{2}{|c|}{$\begin{array}{l}\text { Transmission heat transfer } \\
\text { coefficient, } \mathbf{H}_{\mathrm{T}, \psi}, \mathrm{W} / \mathrm{K}\end{array}$} \\
\hline & & & $\begin{array}{l}\text { Simplified } \\
\text { ISO } 14683\end{array}$ & $\begin{array}{l}\text { Detailed } \\
\text { ISO } 10211\end{array}$ & $\begin{array}{l}\text { Simplified } \\
\text { ISO } 14683\end{array}$ & $\begin{array}{l}\text { Detailed } \\
\text { ISO 10211 }\end{array}$ \\
\hline Window frame/ façade outer wall & W18 & 99.37 & 0.200 & 0.037 & 19.874 & 3.677 \\
\hline Roof window frame/ roof on slopes & W4 & 36.93 & 0.150 & 0.090 & 5.540 & 3.324 \\
\hline Intermediate floor/ outer wall & IF1 & 46.4 & 0.000 & 0.005 & 0.000 & 0.232 \\
\hline Interior corner & $\mathrm{C} 5$ & 5.02 & 0.050 & 0.027 & 0.251 & 0.136 \\
\hline Ventilation duct/ outer wall & - & 2.26 & - & 0.045 & - & 0.102 \\
\hline Chimney/ roof on top & - & 1.31 & - & 0.057 & - & 0.075 \\
\hline Crossbeam/ outer wall & B1 & 2.4 & 0.950 & 0.074 & 0.380 & 0.017 \\
\hline Roof on slopes/ end wall & R9 & 17.64 & -0.050 & -0.084 & -0.882 & -1.482 \\
\hline Exterior corner & $\mathrm{C} 1$ & 20.25 & -0.050 & -0.074 & -1.013 & -1.499 \\
\hline Roof on slopes/ façade outer wall & R9 & 39.16 & -0.050 & -0.043 & -1.958 & -1.684 \\
\hline TOTAL & & 331.11 & & & 58.627 & 1.686 \\
\hline
\end{tabular}

The greatest extra heat loss due to thermal bridges occurs at the junction of the wall and window frames when it is calculated according to the detailed calculation method given in the standard LVS EN ISO 10211 [2]. The construction solution at this junction should be improved by overlaying insulation material over the window frame, although this is hard to achieve with roof windows. The length of thermal bridges is another important factor in the case of windows, since almost the entire south façade of the building is covered by windows, and there is a row of windows on the south side of the roof. The thermal bridge 2-D model of the junction between the roof window and the roof itself is illustrated in Figure 2.

Ventilated air is a layer with thickness of $60 \mathrm{~mm}$ illustrated in Figure 2. Since air is moving, it actually transfers heat very well, and thus the thermal conductivity was assumed $240 \mathrm{~W} /(\mathrm{m} \cdot \mathrm{K})$. The dimensions illustrated together with the thermal bridge model in Fig. 2 are related to the materials given in Table I, except the width (not thickness) of the roof window frame is shown in Fig. 2.

It must be taken into account that thermal bridges do not always mean extra heat loss. When external dimensions are used, the linear thermal transmittance is negative for thermal bridges occurring at the junctions between the wall and slab or roof.

Continuous thermal insulation is achieved at these junctions.

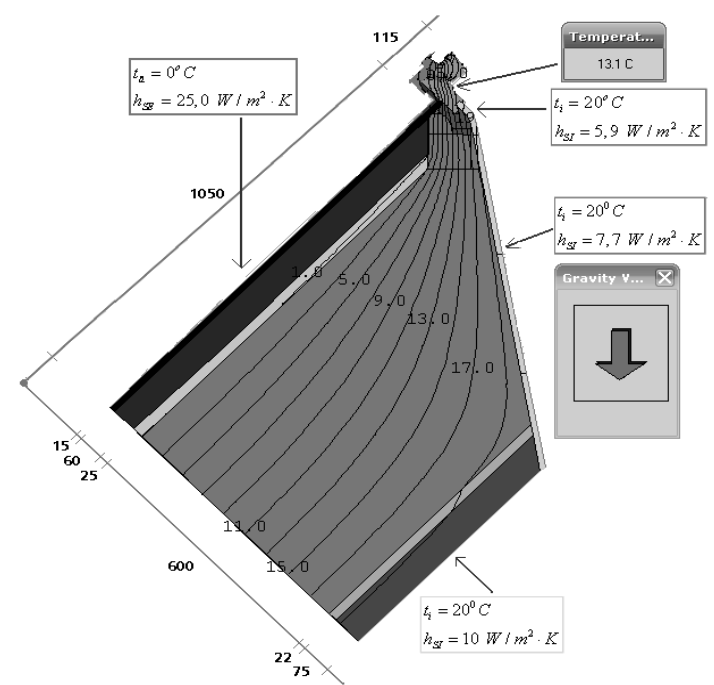

Fig. 2. Thermal bridge at the junction of the roof window frame and the roof itself in 2-D model with dimensions of material layers in $\mathrm{mm}$ and boundary conditions.

The overall transmission heat transfer coefficient of the building envelope was calculated according to (2). If one looks at the overall transmission heat transfer coefficient as the sum of two components, then the sum of heat losses through the building elements and heat losses through thermal bridges is:

$$
\mathrm{H}_{\mathrm{T}}=\mathrm{H}_{\mathrm{T}, \psi}+\mathrm{H}_{\mathrm{T}, \mathrm{U}}=1.69+99.97=101.65, \mathrm{~W} / \mathrm{K} .
$$


The proportion of heat loss through thermal bridges in total transmission heat losses through the building envelope was calculated according to (3). In order to calculate the transmission heat transfer coefficient's thermal bridges component $\left(\mathrm{H}_{\mathrm{T}, \psi \geq 0,01}\right) \quad$ only thermal bridges with $\psi \geq 0.01 \mathrm{~W} / \mathrm{m} \cdot \mathrm{K}$ from Table II were used, therefore $\mathrm{H}_{\mathrm{T}, \psi \geq 0,01}=7.807 \mathrm{~W} / \mathrm{K}$. This information allowed determining that $7.7 \%$ of the total transmission heat losses occur due to thermal bridges, as it is illustrated in Figure 3.

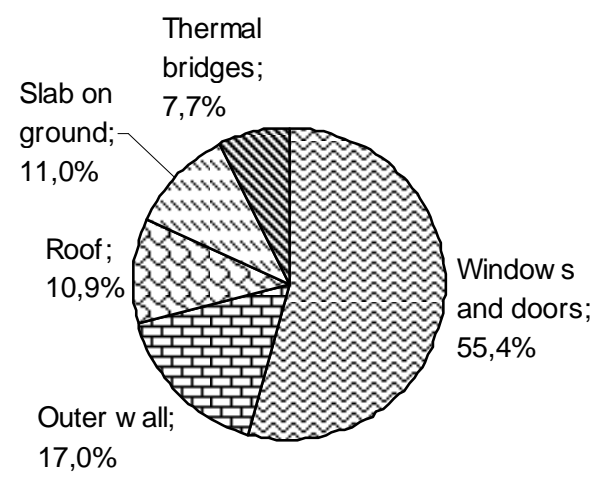

Fig. 3. Transmission heat losses in low-energy building.

Although construction solutions differ from building to building, the results obtained in this study can be compared with results from buildings with similar construction solutions. Linear thermal transmittances given in Table II show a wider range than in common practice in Passive House institute partner countries (from $\psi=-0.03$ to $\psi=0.030 \mathrm{~W} /(\mathrm{m} \cdot \mathrm{K})$ ) [11]. This is attributed to the higher quality of construction solutions used in passive houses. It is probably most difficult to construct a model displaying thermal bridge at the junction of the wall and slab, however results from the thermal bridge atlas created for the AECB's CarbonLite programme [4] and from real houses in Great Britain that were renovated using this programme [13].

The linear thermal transmittances from Table II are close to those achieved in the low-energy detached house with construction solutions typical for Switzerland. Building elements in this detached house all have similar thermal transmittances as given in Table I. However, the biggest differences between the results in Table II and the Swiss house were found at the junctions of the window frame and wall $(\psi=0.010 \mathrm{~W} /(\mathrm{m} \cdot \mathrm{K})$ versus $\psi=0.037 \mathrm{~W} /(\mathrm{m} \cdot \mathrm{K})$ from Table II), as well as at the junction of the wall and slab on ground $(\psi=0.050 \mathrm{~W} /(\mathrm{m} \cdot \mathrm{K})$ versus $\psi=-0.026 \mathrm{~W} /(\mathrm{m} \cdot \mathrm{K})$ from Table II). For comparison, $6.75 \%$ of the total transmission heat losses in the Swiss low-energy house occur due to thermal bridges [12].

\section{CONCLUSION}

In conclusion, the proportion of the overall heat loss due to thermal bridging in the first one-family low-energy building in Latvia is slightly higher than is common practice with lowenergy buildings. In the investigated building, thermal bridges are responsible for $7.7 \%$ of heat transmission losses through its envelope. The results suggest that even more attention should be paid to the quality of construction solutions, especially at the junctions between window frames and the outer wall.

It is now clear that the simplified method described in the standard LVS EN ISO 14683 cannot be used for low-energy buildings. Construction solutions applied to these buildings differ too much from the constructions solutions assumed to create the thermal bridge atlas.

The knowledge acquired through this study will help stakeholders involved in constructing low-energy buildings to make more educated decisions about construction design in order to avoid excess heat losses due to thermal bridging.

\section{REFERENCES}

1. Janssens A., Londersele E.V., Standaert P., Vandermarcke B., Wouters P., and Roels S. Development of Limits for the Linear Thermal Transmittance of Thermal Bridges in Buildings, Gent: 2007, p 10.

2. European Committee for Standardization, Thermal bridges in building construction - Heat flows and surface temperatures - Detailed calculations, LVS EN ISO 10211:2008, 2007.

3. Gustavsen A., Vincent T., Blom P. e.a. "Kuldebroer - Beregning , kuldebroverdier og innvirkning på energibruk," 2008, p 49.

4. AECB, "CarbonLite Programme, Volume 5: Steps two \& three design guidance - Gold Standart," vol. 5, 2009, p. 133.

5. Huizenga C., Arasteh D., Finlayson E. e.a. "THERM 2.0: A Building component model for steady-state two-dimensional heat transfer," Building Simulation '99, IBPSA, Berkeley: 1999, p. 7.

6. European Committee for Standardization, Thermal bridges in building construction - Linear thermal transmittance - Simplified methods and default values, LVS EN ISO 14683:2008, 2007.

7. "Latvian Building Code LBN 002-01 Thermal performance of building envelopes," 2001

8. Larbi A.B. "Statistical modelling of heat transfer for thermal bridges of buildings," Energy and Buildings, vol. 37, 2005, pp. 945-951.

9. Tilmans A. and Orshoven D. "Software and atlases for evaluating thermal bridges," ASIEPI project, vol. 10, 2009, p. 10

10. European Committee for Standardization, Building components and building elements - Thermal resistance and thermal transmittance Calculation method, LVS EN ISO 6946:2008A, 2008.

11. Strom I., Joosten L., and Boonstra C. Promotion of European Passive Houses, 2006, p 50

12. Faninger G. "Heat Bridges in Building Constructions : Requirements for Sustainable Housing and Solutions," pp. 1-28.

13. Simmonds A. and Clarke A. "Radical renovation to CarbonLite standards," Green Building Magazine, 2007, pp. 14-22.

Martins Pelss, B.Sc.

Institute of Energy Systems and Environment, Riga Technical University Kronvalda boulevard 1,LV1010, Riga, Latvia Phone: +371 7089923, Fax +371 7089908

e-mail: mpelshs@yahoo.co.uk

Agris Kamenders, M.Sc.

Institute of Energy Systems and Environment, Riga Technical University Address: Kronvalda Boulevard 1, LV-1010, Riga, Latvia

Phone:: +371 7089923, Fax +371 7089908

e-mail: agris.kamenders@rtu.lv

Andra Blumberga, Dr.Sc.Ing., Professor

Riga Technical University, Institute of Energy Systems and Environment Address: Kronvalda Boulevard 1, LV-1010, Riga, Latvia

Phone: +371 7089923, Fax +371 7089908

e-mail: andra.blumberga@rtu.lv 
Mārtin̦š Pelšs, Andra Blumberga, Agris Kamenders. Termisko tiltu ietekme uz siltumenerğijas patēriṇu apkurei zema-patēriṇa dzīvojamajā ēkā

Termiskais tilts visbiežāk veidojas divu vai vairāku atškirīgu ēkas būvelementu savienojuma vietās, piemēram, starp loga rāmi un ārsienu. Savienojuma vietā ir novērojama paaugstināta siltuma plūsma sal̄̄dzinājumā ar siltuma plūsmu caur būvelementu virsmām. Termiskie tilti palielina siltuma zudumus caur ēku norobežojošajām konstrukcijām, palielinot siltumenerǵijas patērinu tajās, kā arī atstāj negatīvu ietekmi uz iekštelpu klimatu un samazina ēkas norobežojošo konstrukciju mūžu.

Šì darba mērḳis bija novērtēt termisko tiltu ietekmi uz zema patēriṇa dz̄̄vojamās ēkas enerğijas patēriṇu. Latvijas būvnormatīvā LBN 002-01 ir norādītas divas termisko tiltu aprēkina metodes - vienkāršotā un detalizētā (saskanā ar standartiem LVS EN ISO 14683 un LVS EN ISO 10211 attiecīgi). Abas aprēkina metodes ir izmantotas un iegūtie rezultāti ir savstarpēji salīdzināti zema patēriņa ēkas termisko tiltu aprēķinam. Detalizētās aprēķina metodes pamatā ir divdimensiju termisko tiltu datormodeli, kuri, balsoties uz ēkas rasējumiem, tika konstruēti, izmantojot datorprogrammu THERM.

Detalizētā aprēķina metodes ceḷā iegūtie rezultāti liecina, ka zema patēriņa ēkā siltuma zudumi caur termiskajiem tiltiem sastāda 7,7\% no kopējiem siltuma zudumiem caur ēkas norobežojošo konstrukciju. Lielāko daḷu no šiem papildu zudumiem veido termiskie tiltu logu rāmju savienojuma vietā ar ārsienu. Vienkāršotā aprēķina metode, kas aprakstīta standartā LVS EN ISO 14683, nevar tikt izmantota zema patēriņa ēkas termisko tiltu aprēkinam, jo termisko tiltu katalogs neapmierinoši apraksta konstrukcijas zema patēriṇa ēkā. Ja nav iespējams veikt detalizētāku aprēksinu, tad daudz precīzāk ir pieṇemt, ka ēkā termisko tiltu vienkārši nav, nekā izmantot standartā LVS EN ISO 14683 aprakstīto metodi termisko tiltu ietekmes noteikšanai zema patēriņa ēkai.

Мартиньш Пелш, Андра Блумберга, Агрис Камендерс. Влияние тепловых мостов на потребление энергии в энергосберегающем доме

Тепловые мосты, как правило, проявляются на стыках различных элементов здания, например, между рамой окна и наружной стеной, где трудно добиться непрерывности теплоизоляционного слоя. На стыках происходит повышение теплового потока по сравнению с тепловым потоком через строительные элементы поверхности стен. Тепловые мосты увеличивают потери тепла через оболочку здания, увеличивая потребление энергии в них. Данная работа направлена на оценку воздействия тепловых мостов в жилых зданиях низкого потребления энергии. В строительном нормативе LBN 002-01 указано два метода расчета тепловых мостов - упрощенный и детализированный (в соответствии со стандартами ISO 14683 и ISO 10211 соответственно). Оба расчетных метода использованы и приведены в сравнительной характеристике для расчетов тепловых мостов в строительстве зданий низкого потребления энергии. В основе метода детальных расчётов находятся двумерные компьютерные модели тепловых мостов, которые конструируются на основе строительных чертежей, используя компьютерную программу THERM.

Результаты, полученные путём метода детальных расчётов, показывают, что в доме с низким потреблением энергии теплопотери через тепловые мосты составляют 7,7\% от общих теплопотерь через ограждающую конструкцию здания. Большую часть этих дополнительных потерь создают места соединения тепловых мостов оконных рам с наружными стенами. Упрощённый метод расчётов, который описан в стандарте LVS EN ISO 14683, не может быть использован для расчёта тепловых мостов в домах с низким энергопотреблением, так как каталог термических мостов неудовлетворительно описывает конструкции таких домов. Если делать детальный расчёт невозможно, то наиболее точно будет принять, что в доме тепловых мостов просто нет, нежели использовать в LVS EN ISO 14683 стандарте описанный метод определения влияния тепловых мостов на дом с низким энергопотреблением. 